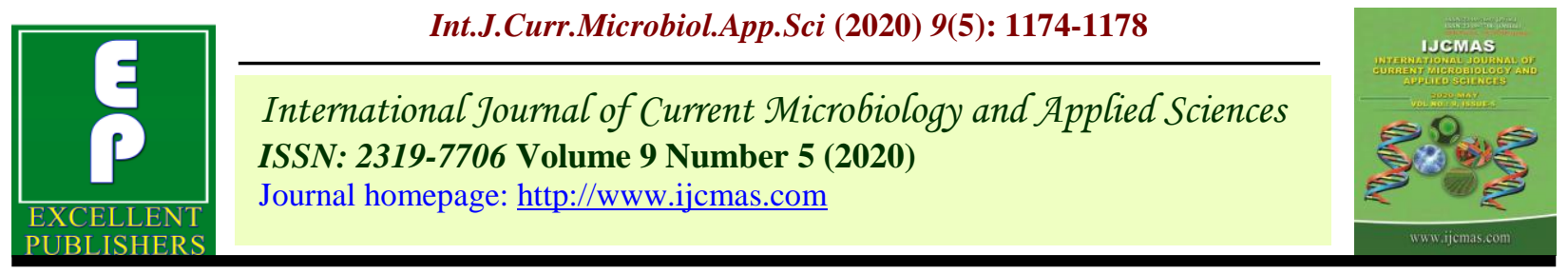

Original Research Article

https://doi.org/10.20546/ijcmas.2020.905.129

\title{
Cultivation of Azolla (Azolla pinnata) and its Use as Cattle Feed Supplement
}

\author{
Upendra Kumar*, M.L. Reager and B.S. Mitharwal \\ Krishi Vigyan Kendra, Bikaner-I, Swami Keshwanand Rajasthan Agricultural University, \\ Bikaner (Rajasthan) 334006, India \\ *Corresponding author
}

\begin{abstract}
A B S T R A C T
Keywords

Azolla,

Cattle Feed

Supplement

Article Info

Accepted:

10 April 2020

Available Online:

10 May 2020

Azolla (Azolla pinnata) has enormous potential as a livestock feed due to its high content of protein, essential amino acids, vitamins, growth promoter intermediaries and minerals. Azolla, on a dry weight basis, is constituted of $25-35 \%$ protein content, $10-15 \%$ mineral content and 7-10\%, a combination of amino acids, bio-active substances and biopolymers. This technology of cultivation of Azolla was transferred through conductance of demonstrations in ten villages. Feeding of Azolla as livestock feed to milch animals resulted in increase in milk yield and fat content. The biocomposition of Azolla, makes it one of the most economic and efficient feed substitutes for livestock. Moreover, Azolla can be easily digested by livestock, owing to its high protein and low lignin content.
\end{abstract}

\section{Introduction}

Despite being largest producer of milk, in India there acute Shortage of dry fodder, green fodder and concentrate for dairy animals. The shortage of fodder is therefore, compensated with the use of readymade commercial feed resulting in increased cost of milk production. The search for alternatives to green fodder and concentrates led to a wonderful plant Azolla, which holds the promise of providing a sustainable feed for livestock. The water fern Azolla (Azolla pinnata) is an unconventional feed ingredient. Azolla is a free floating fresh water fern belonging to the family Azollaceae and order
Pteridophyta. Azolla is a potential feed ingredient for livestock. Azolla is rich in protein, total protein is $25-30 \%$. Azolla can be used as a plant protein source. It is also a potential source of nitrogen and is a potential feed ingredient for livestock (Lumpkin, 1984). Azolla can increase flexibility of diet and makes possibility for cheaper production in livestock breeding and have been known as the cheapest and most abundant potential protein sources, because they are able to synthesize amino acids and a wide range of available and unlimited raw materials (Alalade and Iyayi, 2006). Traditional supplements based on oilseed cakes are expensive. One alternative is the plant 
“Azolla (Azolla pinnata) which floats on the surface of water by means of numerous, small, closely overlapping scale-like leaves, with their roots hanging in the water. They form a symbiotic relationship with the cyanobacterium Anabaena azollae, which fixes atmospheric nitrogen, giving the plant access to this essential nutrient. Azolla has been used successfully as a protein supplement to replace meal in diets for livestock. According to Ambade et al., (2010), milk yield was increased by 15 to $20 \%$ after feeding azolla in the diet of dairy cows.

\section{Environmental requirements}

Azolla is found in ponds, ditches, and wetlands of warm temperate and tropical regions throughout the world. It must grow in water or wet mud, and it dies within a few hours under dry conditions. Azolla can survive a water $\mathrm{pH}$ range of $3.5-10$, but optimum growth occurs when the water is between $\mathrm{pH} 4.5$ and 7 . The optimum temperature for azolla is required 18 to $28^{\circ} \mathrm{C}$. The growth rate gradually declines as salinity increases. Azolla grows in partial shade 50\% sunlight, with growth decreasing quickly under heavy shade. Azolla is established by vegetative propagation. Nursery ponds are generally used to supply a large enough volume to a wetland field to ensure quick coverage.

\section{Cultivation of Azolla}

Establish a small pit of $6.0 \times 1.0 \times 0.2 \mathrm{mt}$ size under the tree shade

Cover this pit with a layer of plastic sac to protect from the intruding root system and then with silpauline sheet $\left(\begin{array}{ll}120 & \text { G }\end{array}\right)$ thickness

Apply $80-90 \mathrm{~kg}$ of soil into this silpauline sheet lined pit

Fill the pit with water $10 \mathrm{~cm}$ and mix 10-15 $\mathrm{kg}$ of cow dung into this.

Two kg of azolla pinnatta into this water bath and mix this bath once in 2-3 days and remove any excessive fallen tree leaves in order to maintain the $\mathrm{pH}$ only in neutral $\mathrm{pH}$ the azolla will grow well.

Azolla will multiply at a faster rate and will double in its volume by every $3-4$ days, once the entire water bath is fully covered by floating azolla then it is ready for harvest.

\section{Precautions}

A shady place, preferably under a Nylon Shady net $50 \%$, with sufficient sunlight should be chosen for the Azolla production unit. A place of direct sunlight should be avoided.

All corners of the pit should be of the same level so that the water level can be maintained uniformly.

Azolla biomass @ 300 gms - 350 gms /sq.meter should be removed daily to avoid overcrowding and for keeping the fern at rapid multiplication phase.

Suitable nutrients should be supplied, as and when, nutrient deficiency is noticed.

Plant protection measures against pests and diseases should be taken as and when required,

About $5 \mathrm{~kg}$ bed soil should be replaced with fresh soil, once in 30 days, to avoid nitrogen build up and prevent micronutrient deficiency.

Twenty five to thirty per cent water also needs to be replaced with fresh water, once in 10 days, to prevent nitrogen build up in the bed.

Replacement of water and soil should be followed by fresh inoculation of Azolla, at least once in six months.

A fresh bed has to be prepared and inoculated with pure culture of Azolla, when contaminated by pest and diseases. 


\section{Utilization of Azolla as cattle feed}

Azolla should be harvested with a plastic tray having holes of 1 sq.cm mesh size to drain the water. The tray along with Azolla should be kept in a bucket, half filled with water. Azolla should be washed to get rid of the cow dung smell. Washing also helps in separating the small plantlets which drain out of the tray. The plantlets along with water in the bucket can be poured back in to the original bed. Azolla fed to cattle after mixing in concentrate ratio in $1: 1$ ratio. 1.5 to $2.0 \mathrm{Kg}$ of Azolla may be fed to milch animal per day. However, it is advisable to mix Azolla inregular feed in 1:1 ratio at the beginning, for one week. After a fortnight of feeding on Azolla mixed with regular feed, livestock may be directly fed with Azolla, without the addition of regular feed material.

\section{Materials and Methods}

The present study was carried out in the Bikaner district of Rajasthan, India. Ten villages were selected namely Benisar, Kanasar, 10 KYD, 5 KYD, Siyana, Nania, Dasori, Bikaner, Khara and Gusaisar by selecting five farmers from each village. Thus, a total of 50 farmers and two Rathi cows each from each farmer were taken to study the impact of feeding of Azolla. The livestock owners were proper trend by on and off campus practical training on azolla production technology, according to Kamalasanana et al., (2002). Approximately 1.5 to $2.0 \mathrm{Kg}$. fresh Azolla was fed to the milch animals per day along with usual ration. The animals were maintained on chaffed fodder at ad lib and 3 to $4 \mathrm{~kg}$ of commercial concentrate mixture. These selected animals had already completed a period of three months of lactation period. The observations on milk yield and milk fat percentage was recorded for three months starting from 15 days after the Azolla feeding of animals.

\section{Results and Discussion}

The present study was undertaken to know effect of feeding Azolla on milk yield of lactating cows under field conditions. The milk yield showed increasing trend and it increased to $9.90 \mathrm{~L} /$ day from $8.30 \mathrm{~L} /$ day after 90 days of feeding of azolla per day with conventional feed. The data revealed there was 19.51 per cent increase in milk yield of cows. It is in conformation with Singh et al., 2017, Mathur et al., (2013) and Kamalasanana et al., (2002) in buffaloes. Gouri et al., (2012), Ambade et al., (2010), Rawat et al., (2015) and Gowda et al., (2015) found similar results in cross bred cows. Meena et al., and Singh et al., (2017) also reported the milk yield increased in buffaloes. The fat percent increase from 1.96 per cent in cows (Table 1).

Kamalasanana et al., (2002) and Mathur et al., (2013) also found an increase in milk fat yield when Azolla was combined with regular feed, and that 15-20 per cent of commercial feed could be replaced with the same quantity of Azolla on dry weight basis without affecting milk production, providing a 20 to 25 per cent savings on buying commercial feeds. Therefore, the livestock owners may fed it to all ruminant animals on all stages of growth and production and the problems likeLate maturity, Low milk yield, Short milking period, Long dry period, Milk fever, Prolapsed of Uterus, Repeat breeding etc. may overcome. General reaction of the farmers was that the animal starts showing excellent sign of health such as improved hair coat condition, brightness in eyes, moist muzzle and always activeness after feeding of Azolla. 
Table.1 Economics of Azolla production

\begin{tabular}{|c|c|c|c|}
\hline Kuccha Trench & $\begin{array}{l}\text { Cost } \\
\text { (Rs.) }\end{array}$ & Pucca Trench & Cost (Rs) \\
\hline $\begin{array}{l}\text { Digging charges of trench (size } \\
\text { of unit }(6.0 \times 1.0 \times 0.2 \mathrm{mt})\end{array}$ & 200.00 & 200 Bricks@ Rs.5/- Brick & 1000.00 \\
\hline \multirow[t]{2}{*}{ Cost of silpauline sheet (120 G) } & 450.00 & Cement 3 bags @ Rs. 310/- & 930.00 \\
\hline & & Gitti + Sand & 600.00 \\
\hline $\begin{array}{l}\text { Nylon Shady net } 50 \text { \% ( } 7 \text { x } 2 \text { mt) } \\
\text { @ Rs. 30/- mt }\end{array}$ & 420.00 & $\begin{array}{l}\text { Nylon Shady net } 50 \% \text { ( } 7 \text { x } 2 \\
\text { mt) @ Rs. 30/-mt }\end{array}$ & 420.00 \\
\hline Azolla 2 kg @ Rs. 50/-kg & 100.00 & Azolla 2 kg@ @s. 50/-kg & 100.00 \\
\hline $\begin{array}{l}\text { Cow dung } 50 \text { kg (10-15 kg.+ } \\
5 \mathrm{~kg} . / \mathrm{month})\end{array}$ & 150.00 & $\begin{array}{l}\text { Cow dung } 50 \mathrm{~kg}(10-15 \mathrm{~kg} .+ \\
5 \mathrm{~kg} . / \mathrm{month})\end{array}$ & 150.00 \\
\hline \multirow[t]{2}{*}{$\begin{array}{l}\text { Super phosphate } 240 \text { gms @20 } \\
\text { gm. / month }\end{array}$} & 10.00 & $\begin{array}{l}\text { Super phosphate } 240 \text { gms } \\
\text { @ } 20 \text { gm. / month }\end{array}$ & 10.00 \\
\hline & & Labour charge & 1000 \\
\hline Total & 1330.00 & Total & 4210.00 \\
\hline
\end{tabular}

Table.2 Effect of feeding of Azolla on Milk and Fat

\begin{tabular}{|l|c|c|c|c|}
\hline Parameter & Initial & Final & Difference & \% Increase \\
\hline Milk Yield (1/d) & 8.30 & 9.90 & 1.60 & 19.51 \\
\hline Milk Fat (\%) & 5.1 & 5.2 & 0.1 & 1.96 \\
\hline
\end{tabular}

\section{References}

Alalade, O.A., Iyayi, E.A. Chemical composition and the feeding value of Azolla pinnata meal for egg-type chicks. Int. J. of Poult. Sci., 5: 137-141.

Ambade R B, Jadhav S N and Phalke N B (2010). Impact of azolla as a protein supplement and its Influence on feed utilization in livestock. Livestock line. 4 (4): 21-23.

Gouri Mahadevappa D, Sanganal Jagadeesh $\mathrm{S}$, Gopinath $\mathrm{CR}$, and Kalibavi CM (2012). Importance of azolla as a sustainable feed for livestock and poultry. Agric Review. 33 (2): 93-103.

Gowda NKS, Manegar A, Verma S,
Valleesha NC, Maya G, Pal DT, Suresh KP (2015). Azolla (Azolla pinnata) as a Green Feed Supplement for Dairy Cattle-An On Farm Study. Anim Nutr \& Feed Tech, 15 (2): 283-287.

Kamalasanana P, Premalatha S, and Rajamony S, (2002). Azolla - A sustainable feed substitute for livestock. Leisa India. March 2002, pp 15-17.

Mathur GN, Sharma Ramakant and Choudhary PC (2013). Use of Azolla (Azolla pinnata) as Cattle Feed Supplement. J. Krishi Vigyan 2 (1): 7375.

Meena, G.S., B.L. Dhaka, Bacchu Singh, R.K. Meena and Meena, K.C.( 2017). Effect of Azolla as Feed Supplement on Milk Yield in Buffaloes. 
Int.J.Curr.Microbiol.App.Sci. $\quad 6(12)$ : 3490- 3494.

Rawat Nidhi, Kumari K, Singh F, Gilhare VR (2015). Effect of Azolla-supplemented feeding on milk production of cattle and production performance of broilers. Applied Biological Research 17 (2):
(214- 218).

Singh Bacchu, Meena G. S, Meena K. C, Meena R. K, Singh Bachchu and Indoria Deepa (2017). Effect of a Wonder herb Azolla on Buffaloes Milk Yield. Int. J. Curr. Microbiol. App. Sci 6 (11): $1-8$.

\section{How to cite this article:}

Upendra Kumar, M.L. Reager and Mitharwal, B.S. 2020. Cultivation of Azolla (Azolla pinnata) and its Use as Cattle Feed Supplement. Int.J.Curr.Microbiol.App.Sci. 9(05): 11741178. doi: https://doi.org/10.20546/ijcmas.2020.905.129 